\title{
Modulation of Calcium Channels in Human Retinal Glial Cells by Basic Fibroblast Growth Factor: A Possible Role in Retinal Pathobiology
}

\author{
Donald G. Puro' and Tomiya Mano² \\ 'Departments of Ophthalmology and Physiology, University of Michigan School of Medicine, Ann Arbor, Michigan 48105 \\ and ${ }^{2}$ Department of Ophthalmology, University of Miami School of Medicine, Miami, Florida 33101
}

The objective of this study was to begin to examine the cellular and biophysical effects on human retinal glial cells of basic fibroblast growth factor (bFGF), which is endogenous to the retina and likely to play a role in retinal pathobiology. Experiments were performed on cultured glial cells derived from the adult postmortem retina. A proliferative response to bFGF established a sensitivity of the retinal glia to this growth factor. The possibility that bFGF alters calcium currents was assessed using the whole-cell recording configuration of the patch-clamp technique to analyze inward currents carried by barium. Two types of voltage-gated calcium channels could be expressed by the glial cells. One, similar to the T-type current described in various kinds of cells, had a low threshold of activation, a transient response, and an insensitivity to the dihydropyridine nifedipine. The other type of inward current, which closely resembles the L-type calcium current found in other cells, had a high threshold, had a long-lasting response, and was inhibited by nifedipine. When continuous whole-cell recordings were made from retinal glial cells, the L-type calcium current increased significantly within $\mathbf{2 0}$ min after exposure of the cells to bFGF. The physiological significance of this modulatory effect remains uncertain, though the observation that nifedipine inhibits both the L-type calcium current and the bFGF-induced proliferation is consistent with the hypothesis that dihydropyridine-sensitive channels may play a role in modulating the mitogenic response of retinal glial cells to this growth factor.

Although basic fibroblast growth factor (bFGF) is thought to play a role in the pathobiology of the CNS (Gospodarowicz et al., 1986; Sievers et al., 1987; Finkelstein et al., 1988; Faktorovich et al., 1990; Sivalingam et al., 1990), knowledge of its effects on cells of the nervous system is limited. In this article, we begin to examine the effects of bFGF on human retinal glial cells. Retinal glial cells were chosen for study for a number of reasons. One reason is recent evidence indicating that these cells have bFGF receptors (Mascarelli et al., 1990) and thus are likely to be targets for this growth factor, which is endogenous to the retina. A second reason for studying bFGF-glial interactions is

\footnotetext{
Received July 26, 1990; revised Dec. 27, 1990; accepted Jan. 21, 1991.

This work was supported by Grants EY06931, EY02180, and EY07003 from the National Eye Institute, NIH, Bethesda, MD.

Correspondence should be addressed to Donald G. Puro, M.D., Ph.D., W. K. Kellogg Eye Center, University of Michigan, 1000 Wall Street, Ann Arbor, MI 48105.

Copyright (C) 1991 Society for Neuroscience $0270-6474 / 91 / 111873-08 \$ 03.00 / 0$
}

that glial cells are important in the pathogenesis of retinal disorders, such as proliferative vitreoretinopathy (a complication of retinal detachment) and proliferative diabetic retinopathy (Van Horn et al., 1975; Hamilton et al., 1982; Hiscott et al., 1984; Nork et al., 1987; Jerdan et al., 1989; Sramek et al., 1989; Guerin et al., 1990), in which bFGF has been postulated to play a role (Gospodarowicz et al., 1986; Sivalingam et al., 1990). Another reason for focusing on retinal glial cells is the availability of a cell culture system to study glia from the adult human retina.

This study addressed two main questions. The initial question was whether the retinal glial cells in our culture system are sensitive to bFGF. Our finding that bFGF is a potent mitogen for these cells answered this question affirmatively. A mitogenic response is of interest in retinal, as well as CNS, pathobiology because glial cell proliferation occurs frequently in response to trauma, ischemia, inflammation, and other pathological conditions.

Knowing that retinal glial cells are sensitive to bFGF led to the second question, which concerns the biophysical effects of this growth factor. Are calcium channels modulated by bFGF? Effects on calcium channels are of interest because studies of nonocular cells indicate that exposure to bFGF may be associated with an influx of calcium from the extracellular space (Magnaldo et al., 1986; Pandrella et al., 1989). This influx of calcium may serve as a signal to help mediate bFGF-induced effects on cell activity. Addressing this question concerning modulation first required determining whether human retinal glial cells express calcium channels. Although at least one type of calcium channel has been identified in glial cells of the salamander retina (Newman, 1985), there are no previous studies of calcium currents in mammalian retinal glial cells. Here, we report that human retinal glial cells in culture can express two types of voltage-gated calcium channels ( $\mathrm{T}$ - and L-types) and that exposure of these cells to bFGF is associated with an increase in the L-type current.

Whether the modulation by bFGF of the L-type calcium current plays a role in mediating the mitogenic effect of this growth factor remains an unresolved issue. However, a link between the modulatory and mitogenic effects of bFGF is suggested by the dihydropyridine sensitivity of both the L-type current and the proliferative response.

\section{Materials and Methods}

Cell cultures. Cultures of retinal glial cells were prepared using a modification (Puro et al., 1990) of methods developed by others (Hjelmeland et al., 1987). Postmortem eyes from donors aged 19 to $88 \mathrm{yr}$ were supplied within $24 \mathrm{hr}$ of death by the Florida Lions Eye Bank or the 
Michigan Eye Bank. Retinas were removed, exposed to a calcium- and magnesium-free phosphate buffer (CMF) supplemented with $0.1 \%$ tryp$\sin (3 \times$ crystallized; Worthington), $0.2 \%$ hyaluronidase (Sigma), and $4 \%$ chicken serum (GIBCO Laboratories) for $45 \mathrm{~min}$ at $37^{\circ} \mathrm{C}$ and then dissociated mechanically in $80 \%$ medium A (1:1 ratio of Dulbecco's modified Eagle's medium and Ham's F12 medium) and 20\% fetal bovine serum. Dissociated cells from one retina were added to three 35 $\mathrm{mm}$ Petri dishes, kept in a humidified environment of $97 \%$ air and $3 \%$ $\mathrm{CO}_{2}$ at $37^{\circ} \mathrm{C}$, and fed with $80 \%$ medium $\mathrm{A}$ and $20 \%$ fetal bovine serum twice per week. Cultures that reached $80-90 \%$ confluency were split to three $35-\mathrm{mm}$ Petri dishes. Cells that had been in culture for three to five passages were used in this study.

The cells were classified as glial by their positive immunocytochemical staining with antibodies to glial fibrillary acidic protein (GFAP). As reported elsewhere (Mano and Puro, 1990; Puro et al., 1990), virtually all of the cells stained positively for GFAP. Ultrastructural studies (Mano and Puro, 1990; Puro et al., 1990) of these cultured cells demonstrated the presence of $10-\mathrm{nm}$ cytoplasmic filaments, which are characteristic of glial cells. In addition, as published previously (Mano and Puro, 1990; Puro et al., 1990), nearly all of the cells in these cultures stained positively by immunocytochemistry with a monoclonal antibody for Müller's cells.

Recording conditions. One day prior to recording, cultures were washed twice and kept in medium B (medium A supplemented with $50 \mu \mathrm{g} / \mathrm{ml}$ transferrin and $30 \mathrm{~nm}$ sodium selenite). Approximately $1-2 \mathrm{hr}$ prior to recording, medium $B$ was replaced with an appropriate bath solution. Unless stated otherwise, the bath solution contained $125 \mathrm{mM} \mathrm{CsCl}, 10$ $\mathrm{mm} \mathrm{BaCl}, 10 \mathrm{~mm}$ glucose, $5 \mu \mathrm{M}$ tetrodotoxin (TTX), and $10 \mathrm{~mm} \mathrm{Ba}-$ HEPES (pH, 7.3). The pipette solution consisted of $140 \mathrm{~mm} \mathrm{CsCl,} 1$ $\mathrm{mM} \mathrm{MgCl}_{2}$, and $10 \mathrm{~mm}$ Cs-HEPES (pH, 7.3). During experiments, the cultures were examined at $400 \times$ magnification with an inverted microscope equipped with phase-contrast optics. Cells selected for wholecell recording had rounded cell bodies with diameters of approximately $50-150 \mu \mathrm{m}$. A bath solution supplemented with 1 or $10 \mu \mathrm{M}$ nifedipine could be miniperfused in the area of a glial cell by applying 0.5 psi of pressure from a pressure ejection system (Medical Systems) to the back end of a pipette with a tip size of approximately $5 \mu \mathrm{m}$ that was positioned about $100 \mu \mathrm{m}$ from the cell being recorded. In experiments examining changes in channel activity after exposure of glial cells to recombinant bovine basic fibroblast growth factor (bFGF, Amgen), $1.5 \mu \mathrm{l}$ of $500 \mathrm{ng} /$ $\mathrm{ml}$ bFGF was added to the bath (total volume, $1.5 \mathrm{ml}$ ). A stock solution $(1000 \times)$ of nifedipine was dissolved in ethanol. Control experiments showed no effect on the calcium currents of $0.1 \%$ ethanol.

Data acquisition and analysis. Ion currents were recorded with the patch-clamp technique using the whole-cell recording configuration (Hamill et al., 1981). Fire-polished pipettes of borosilicate glass (World Precision Instruments; fiber filled) coated with Sylgard \#1 84 (Dow Corning) had resistances of 3-6 M . A Dagan 3900 patch-clamp amplifier was used for whole-cell recording. The pipette potential was adjusted to 0 current flow before establishment of a seal. Pipette capacitance was minimized by capacity compensation circuitry on the patch-clamp amplifier. Series resistance was largely compensated by appropriate circuitry. Cell capacitance was estimated by using circuitry of the Dagan 3910 expander module. Current signals were filtered at $1 \mathrm{kHz}$. Wholecell currents were evoked by command pulses and were sampled (250 $\mu \mathrm{sec} /$ point) by a minicomputer (Vectra ES/12, Hewlett Packard) using pCLAMP software (version 5.5, Axon Instruments) and an analog/digital converter (TL-1 DMA interface, Axon Instruments). Recordings are shown after subtraction of capacity and linear leak currents, determined by taking the average of 15 consecutive hyperpolarizing pulses $1 / 15$ the size of the test potential. Whole-cell recordings from 89 cells were made as part of this study.

Cell proliferation assays. Retinal glial cells from a near confluent culture were removed from the dish by exposure for $15 \mathrm{~min}$ to $0.1 \%$ trypsin in CMF, centrifuged, and resuspended in $7 \mathrm{ml}$ of $80 \%$ medium A and $20 \%$ fetal bovine serum. Aliquots $(0.15 \mathrm{ml})$ of the cell suspension were placed on $8 \times 8$-mm grids that had been imprinted on the bottoms of 35-mm plastic Petri dishes. The grids, which were imprinted using a template (Mecanex SA), contained a $26 \times 26$ array of alphabetically labeled squares. The day following addition of the $0.15 \mathrm{ml}$ suspension of cells, $1.5 \mathrm{ml}$ of $80 \%$ medium A and $20 \%$ fctal bovine serum was added to each dish. On the second day after the initial plating, a baseline cell count was performed for each Petri dish by starting at one corner of the grid and proceeding systematically until at least 100 cells had been counted. Recording the label of the first and last squares of the grid counter permitted rccounting of the same area later. After baseline counting, the Petri dishes were washed twice with Dulbecco's modified Eagle's medium and exposed to medium B, supplemented as needed with various concentrations of bFGF and nifedipine for $2 \mathrm{~d}$. After this period, cells again were counted over the same areas of the grids as were surveyed for the baseline counts. Control experiments showed no effect of up to $0.5 \%$ ethanol, which was the vehicle for nifedipine, on bFGFinduced proliferation.

In experiments examining the incorporation of bromodeoxyuridine (BrdU) into DNA, cells on grid-stamped dishes were exposed for $2 \mathrm{~d}$ to $10 \mu \mathrm{M}$ BrdU in medium B with or without $500 \mathrm{pg} / \mathrm{ml} \mathrm{bFGF}$. BrdU was localized by immunocytochemical methods similar to those used by Yong et al. (1988), except the avidin-biotin-peroxidase method was used here. In brief, cultures were rinsed, then fixed with $70 \%$ ethanol

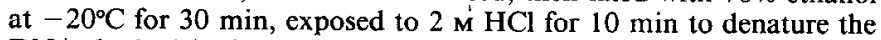
DNA, bathed in $0.1 \mathrm{~m}$ sodium borate $(\mathrm{pH}, 9)$ for $10 \mathrm{~min}$, and then exposed to a monoclonal antibody to BrdU (1:10; Becton Dickinson) for $30 \mathrm{~min}$ at $37^{\circ} \mathrm{C}$. Subsequently, the cultures were incubated in biotinylated anti-mouse IgG antibody (1:1000; Vector) for $30 \mathrm{~min}$ at room temperature, followed by application of the avidin-biotin-peroxidase complex (1:100; Vector) with development in diaminobenzidine.

\section{Results}

\section{Mitogenic response of retinal glia to $b F G F$}

An initial question in this study was whether retinal glial cells are sensitive to bFGF. Because bFGF is a potent mitogen for a variety of cell types, and because glial proliferation occurs in retinal disorders in which bFGF may play a role, the mitogenic effect of this growth factor was assessed. Figure 1 shows the effect of various concentrations of bFGF on the proliferation of human retinal glial cells in culture. A concentration-dependent increase in the number of retinal glial cells was observed. The half-maximally effective concentration of bFGF was approximately $20 \mathrm{pg} / \mathrm{ml}$. A maximal stimulatory effect occurred at concentrations greater than $100 \mathrm{pg} / \mathrm{ml}$.

In addition to assaying cell number, the effect of bFGF on the incorporation of BrdU into the nuclei of the glial cells was determined. BrdU, an analog of the nucleotide thymidine, is incorporated into replicating DNA and can be detected by immunocytochemistry using an anti-BrdU monoclonal antibody. In triplicate experiments, cultures of human retinal glial cclls were exposed for $2 \mathrm{~d}$ to medium B supplemented with $10 \mu \mathrm{M}$ BrdU with or without bFGF (500 pg/ml). Exposure to bFGF was associated with a significantly $(p=0.018$, Student's $t$ test) higher percent of nuclei that were immunoreactive for BrdU. Specifically, immunocytochemistry revealed that $11 \%$ (SE $=$ 3.5 ) of the glial cells in the control plates had nuclei positive for BrdU, while $41 \%$ (SE - 6.9) of the nuclei in the bFGFtreated group stained positively. These experiments demonstrated that the human retinal glial cells in our culture system are sensitive to bFGF.

\section{Two types of voltage-gated calcium channels}

Because an influx of calcium may be one step in a cell's response to bFGF (Magnoldo et al., 1986; Pandrella et al., 1989), we asked whether retinal glial cells have voltage-gated calcium channels that may be affected by this growth factor. Wholc-cell recordings of membrane currents in retinal glial cells were performed with bath and pipette solutions that effectively isolated inward currents carried by barium (see Materials and Methods). Sodium channel current was eliminated by the blocking of sodium channels with $5 \mu \mathrm{M}$ TTX and replacement of external sodium with cesium. Potassium channel current was abolished by having cesium in the bath and pipette solutions and having barium externally. Under these recording conditions, $71 \%(n=$ 


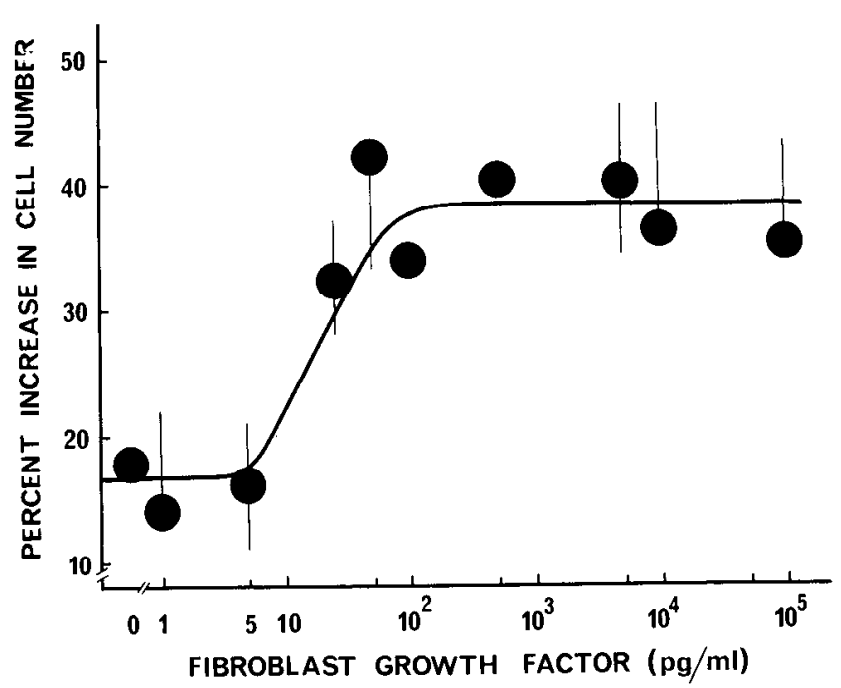

Figure 1. Dose-response curve for the effect of a 2-d exposure to bFGF on the proliferation of human retinal glial cells. Each point represents the mean of at least three experiments. SEs of greater than $1.5 \%$ are shown.

83) of the retinal glial cells sampled had inward currents evoked by depolarization. Typically, there was little "run-down" of barium currents; approximately $90 \%$ of the maximal value for the peak inward current remained after 30 min of successful whole-cell recording. Of the cells with detectable current, the mean peak inward current after $10 \mathrm{~min}$ of recording was -223 $\mathrm{pA}(\mathrm{SE}=22 ; n=59)$. The mean current density was $3.0 \mathrm{pA}$ $\mathrm{pF}(\mathrm{SE}=0.4)$.

Two distinct types of inward currents could be elicited with strong depolarizing pulses: a transient response (Fig. $2 A$ ) and a more long-lasting response (Fig. $2 B$ ). Figure $3 A$ shows leaksubtracted current records evoked by pulses from a holding potential of $-100 \mathrm{mV}$ in a cell that had chiefly a transient type of response. A plot of the voltage dependence of the peak inward current shows a threshold of activation at approximately -55 $\mathrm{mV}$ (Fig. 3B). The inward current increased to a maximum amplitude at $-10 \mathrm{mV}$ and became smaller with progressively greater depolarizing pulses. The voltage dependence of the inactivation of this inward current was examined by varying the holding potential between -100 and $-16 \mathrm{mV}$ before applying a test pulse to $0 \mathrm{mV}$ (Fig. 3C). The peak amplitudes for the inactivation and activation of the current were normalized and plotted against membrane potential in Figure $3 D$. Inactivation was nearly complete at $-40 \mathrm{mV}$, approximately half removed near $-70 \mathrm{mV}$ and fully removed near $-100 \mathrm{mV}$. Activation of this transient current increased markedly over the range of potentials between -60 and $-20 \mathrm{mV}$. Half-maximal activation occurred with pulses to approximatcly $-38 \mathrm{mV}$. This transient inward current appears similar to the T-type of calcium current found in other types of cells (Fox et al., 1987; Bean, 1989).

The characteristics of the long-lasting type of inward current are quite distinct from those for the T-type current. Figure $4 \mathrm{~A}$ shows current records elicited by depolarizing pulses from a holding potential of $-100 \mathrm{mV}$ in a retinal glial cell with a longlasting type of inward current. A plot of the voltage dependence of the peak current shows a steep increase over the range of -25
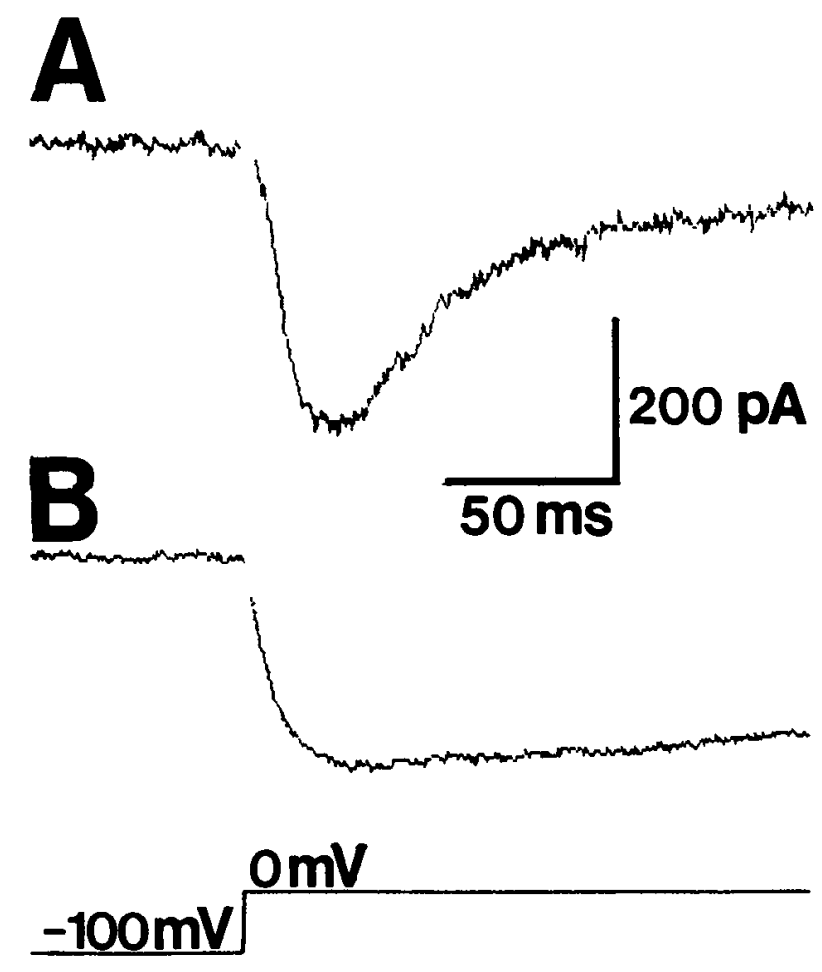

Figure 2. Two types of inward currents observed in human retinal glial cells under whole-cell recording conditions. Currents evoked with pulses from a holding potential of -100 to $0 \mathrm{mV}$. Current traces have been corrected for linear leak and capacitance currents. The bath solution consisted of $125 \mathrm{mM} \mathrm{CsCl}, 10 \mathrm{mM} \mathrm{BaCl}_{2}, 10 \mathrm{~mm}$ glucose, $5 \mu \mathrm{M}$ TTX, and 10 mM Ba-HEPES (pH, 7.3). The pipette solution contained $140 \mathrm{~mm} \mathrm{CsCl}, 1 \mathrm{mM} \mathrm{MgCl}_{2}$, and $10 \mathrm{~mm}$ Cs-HEPES (pH, 7.3). $A$ is from cell $1308-4 ; B$ is from cell $1297-3$.

to $0 \mathrm{mV}$ (Fig. $4 B$ ). This inward current was half-maximal with test potentials to approximately $-13 \mathrm{mV}$ (Fig. $4 B, D$ ). Figure $4 C$ shows the current records when the holding potential was varied before pulsing to $0 \mathrm{mV}$. When normalized and plotted against membrane potential, this inward current was reduced by one-half at a holding potential of approximately $-16 \mathrm{mV}$ (Fig. 4D). Holding potentials more negative than $-30 \mathrm{mV}$ had only modest effects (Fig. 4D). The small degree of activation and inactivation seen in Figure $4 D$ at membrane potentials more negative than $-25 \mathrm{mV}$ is likely to be due to the presence of a small T-type current in this cell. The high-threshold, long-lasting response of this cell is similar to the L-type of calcium current observed in a variety of cell types (Fox et al., 1987; Bean, 1989).

Of the sampled retinal glial cells with voltage-sensitive calcium channels, more than $90 \%$ had both T- and L-currents, based on thresholds for activation. An example of a glial cell with a current-voltage relationship indicating the presence of two types of inward currents is shown in Figure 5. An inward current was initially activated at a threshold of about $-55 \mathrm{mV}$, but increased much more steeply at potentials positive to -15 $\mathrm{mV}$. As was the case for the cell studied in Figure 5, a majority of the sampled cells had L-type currents that were larger than the T-type.

In addition to differences in the voltage dependence of activation and inactivation, $\mathrm{T}$ - and L-type currents in the retinal glial cells could be distinguished pharmacologically. The dihydropyridine nifedipine could reduce the L-type current. In Figure 6 , voltage protocols were chosen to help isolate the T-type 

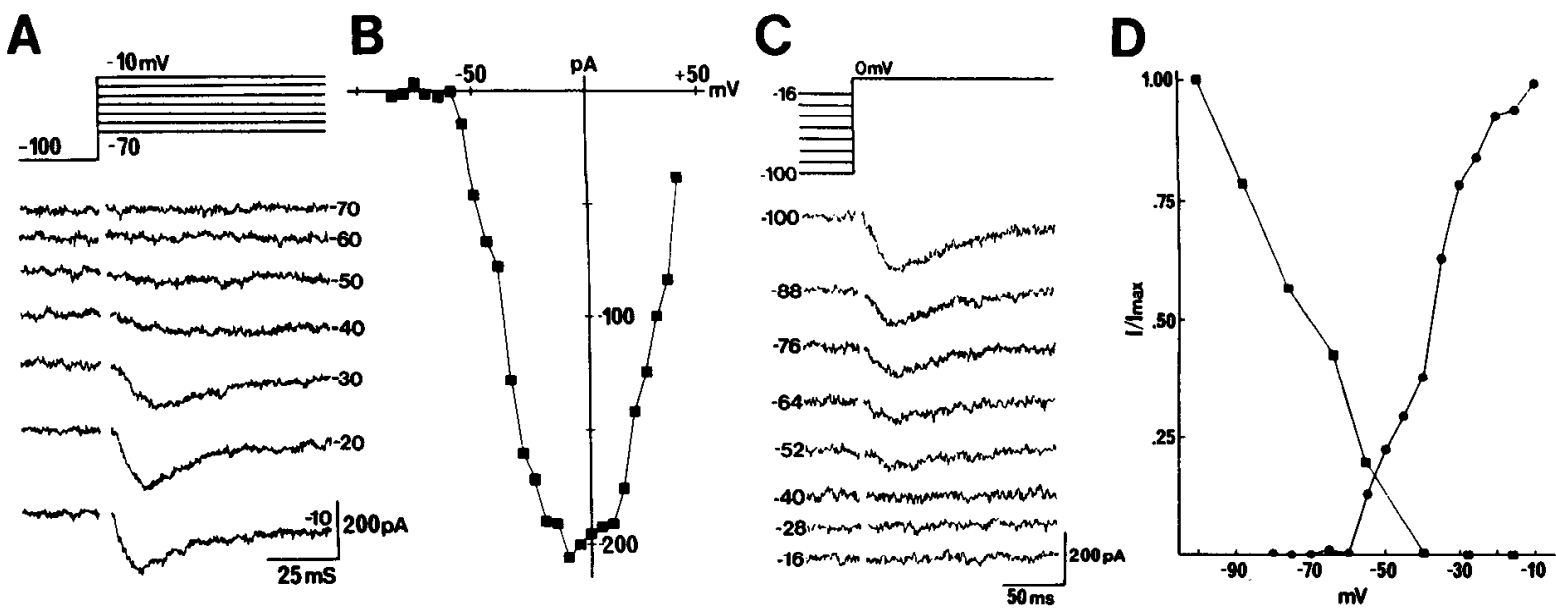

Figure 3. Voltage dependence of activation and inactivation of the transient inward current, from cell 1308-4. A, Currents evoked with pulses from a holding potential of $-100 \mathrm{mV}$ to test potentials of -70 to $-10 \mathrm{mV}$, as indicated. $B$, Peak current plotted against test potential for the same cell as in $A$ (holding potential, $-100 \mathrm{mV}$ ). C, Currents evoked by depolarizations to a test potential of $0 \mathrm{mV}$ from various holding potentials. $D$, Squares show peak current amplitudes (from $C$ ), normalized to the maximal current obtained with a holding potential of $-100 \mathrm{mV}$, plotted against the holding potential. Circles show peak current amplitudes (from $A$ ), normalized to the maximal current obtained at a test potential of - $10 \mathrm{mV}$, plotted against the test potential. Pipette and bath solutions were as in Figure 2.

(Fig. 6A) and the L-type currents (Fig. 6B) in a glial cell. When a bath solution containing $1 \mu \mathrm{M}$ nifedipine was miniperfused in the area of this cell, the L-type current was reduced by approximately $50 \%$, while the T-type current was minimally affected. Reductions in the L-type current of greater than $50 \%$ were not observed even with $10 \mu \mathrm{M}$ nifedipine (five cells tested). There was some variability in the effect of nifedipine on L-type currents. Although four of five tested glial cells had approximately a $50 \%$ reduction in L-type current with perfusion of $10 \mu \mathrm{M}$ nifedipine, one cell had no detectable effect of the dihydropyr- idine. In three cells exposed to a perfusate containing $1 \mu \mathrm{M}$ nifedipine, the reduction in L-type current ranged from approximately $25 \%$ to $50 \%$. Significant reductions in T-type currents were not detected in eight cells exposed to 1 or $10 \mu \mathrm{M}$ nifedipine. Although studies of other cell types indicate that L-type channels have a high affinity receptor for dihydropyridines when the channel is inactivated (Bean, 1989), we observed up to a $50 \%$ inhibitory effect by nifedipine when the L-type channel was in the resting state (Figure $6 B$ ). Voltage dependency of the nifedipine block was not systematically cxamined here.
A
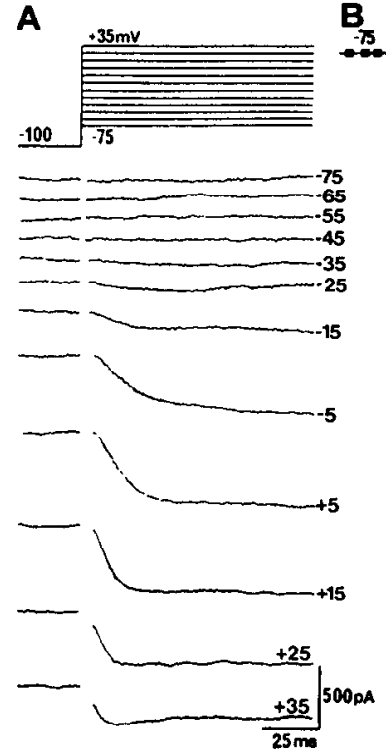
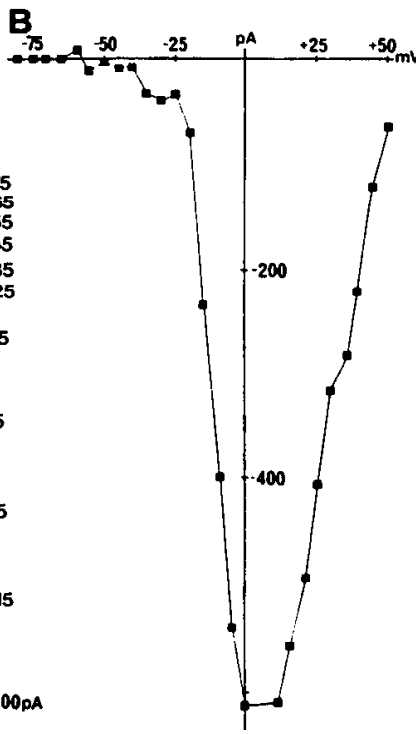

C

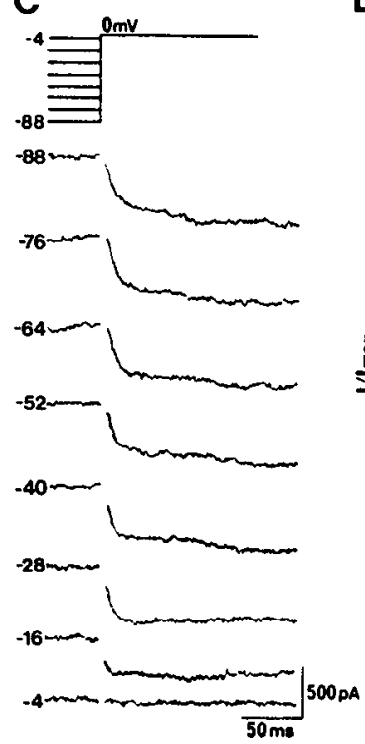

D

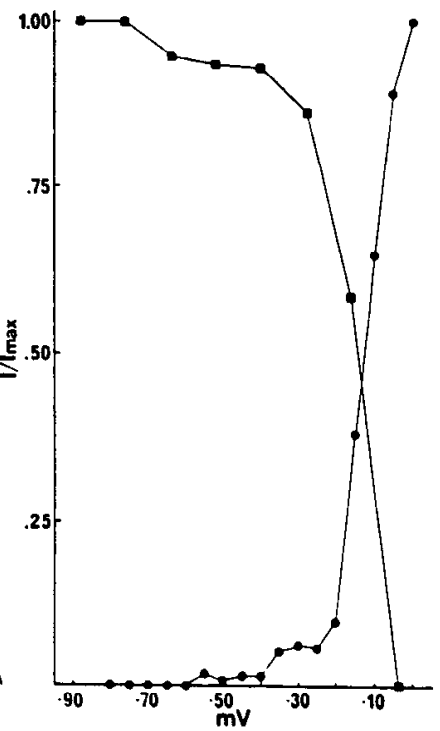

Figure 4. Voltage dependence of the slowly inactivating inward current, from cell 1306-1. A, Currents evoked with pulses from a holding potential of $-100 \mathrm{mV}$ to the test potentials indicated. $B$, Peak current plotted against test potential for the same cell as in $A$ (holding potential, $-100 \mathrm{mV}$ ). $C$, Currents evoked by depolarizations to a test potentials of $0 \mathrm{mV}$ from various holding potentials. $D$, Squares show peak current amplitudes (from $C$ ), normalized to the maximal current obtained with a holding potential of $-100 \mathrm{mV}$, plotted against the holding potential. Circles show peak current amplitudes (from $A$ ), normalized to the maximal current obtained at a test potential of $0 \mathrm{mV}$, plotted against the test potential. Solutions were as in Figure 2. 
Increased inward current after $b F G F$ exposure

The possibility that exposure to bFGF may be associated with a change in the activity of voltage-gated calcium channels was examined. Whole-cell recordings under conditions to isolate currents carried by barium were monitored continuously before and after exposure to bFGF. Figure 7 shows an example of an increase in inward current $14 \mathrm{~min}$ after the onset of miniperfusion in the area of this glial cell with a bath solution containing $500 \mathrm{pg} / \mathrm{ml} \mathrm{bFGF}$. Each trace in Figure $7 A$ is averaged from four runs. The peak current increased by $24 \%$. This difference between the peak currents in the control period and after bFGF exposure was significant ( $p<0.001$, Student's $t$ test). In Figure $7 B$, the current-voltage plots for this cell before and $15-20 \mathrm{~min}$ after exposure to bFGF are shown. The inward current with the higher threshold of activation increased after bFGF exposure, while the inward current elicited at the lower threshold changed little.

In glial cells having predominantly an L-type current, an increase in peak inward current was detected in seven of seven sampled cells. The mean increase elicited with depolarizations from a holding potential of $-100 \mathrm{mV}$ was $40 \%$ (range, $14-100 \%$; $\mathrm{SE}=11 ; n=7$ ) after $10-20 \mathrm{~min}$ of exposure to bFGF. In contrast, in 10 cells with predominantly a T-type current, no increase of greater than $10 \%$ was detected under similar recording conditions, suggesting that exposure to bFGF was associated with a selective increase in L-type currents.

Because guanine nucleotide-binding proteins (G-proteins) are likely to be involved in the regulation of voltage-gated calcium channels in some cell types (Schultz et al., 1990), we examined whether pertussis toxin, an inactivator of G-proteins in many cell types (Graviano and Gilman, 1987), affected the increase in L-type current associated with the exposure of retinal glial cells to bFGF. Cultures were exposed to medium B supplemented with $100 \mathrm{ng} / \mathrm{ml}$ pertussis toxin for $15-22 \mathrm{hr}$ prior to whole-cell recording. During the electrophysiological recordings, pertussis toxin $(100 \mathrm{ng} / \mathrm{ml})$ was in the bath solution. Five cells with L-type currents of at least $100 \mathrm{pA}$ were studied. An increase in peak current of $32 \%(\mathrm{SE}=10)$ was detected within 20 min of the addition of bFGF (final concentration, $500 \mathrm{pg}$ / $\mathrm{ml}$ ) to the bath solution. This increase was not statistically different ( $p=0.5$, Student's $t$ test) from the augmentation found in the absence of pertussis toxin.

\section{Nifedipine inhibits $b F G F$-induced proliferation}

Finding that bFGF exposure was associated with an increase in L-type calcium current led to the question of whether nifedipine, a blocker of the L-type channels (Fig. 6B), could inhibit the proliferative effect of bFGF. As shown in Figure 8, nifedipine does inhibit the bFGF-induced proliferation of retinal glial cells in a dose-dependent manner. The half-maximally effective concentration of nifedipine is approximately $0.5 \mu \mathrm{M}$. Inhibition of proliferation by nifedipine did not appear to be a toxic effect because cell viability was unaffected by a 2-d exposure to $10 \mu \mathrm{M}$ nifedipine as assayed by trypan blue dye exclusion. Also, glial cell number was not reduced in cultures maintained in medium B supplemented with $10 \mu \mathrm{M}$ nifedipine for $2 \mathrm{~d}$. Further evidence for a lack of toxicity was that removal of the nifedipine-containing medium after $2 \mathrm{~d}$ and the subsequent addition of bFGF $(500 \mathrm{pg} / \mathrm{ml})$ for $36 \mathrm{hr}$ led to a $35 \%(\mathrm{SE}=5 ; n=2)$ increase in the number of retinal glial cells. These experiments indicate that

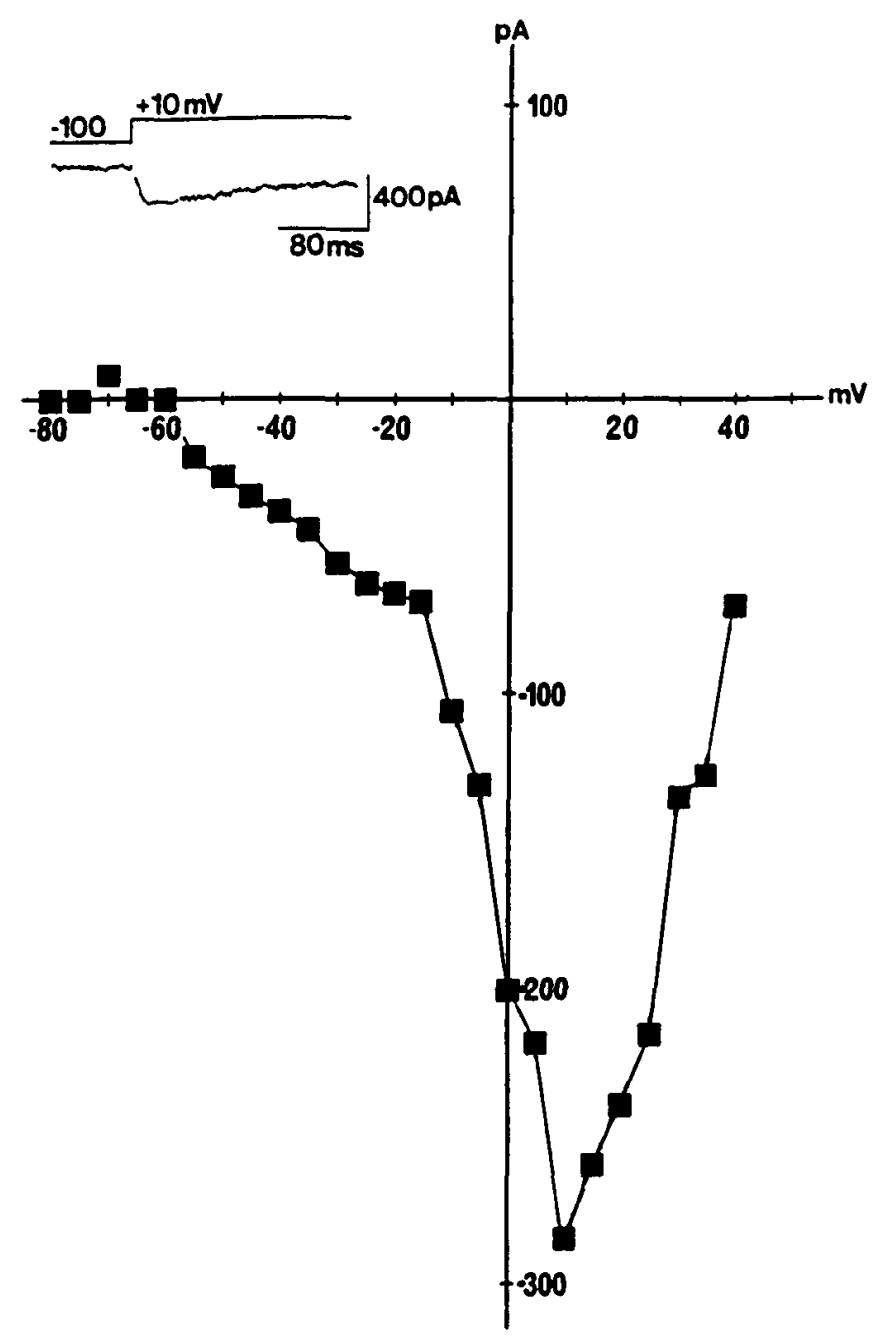

Figure 5. Current-voltage relationship indicating two types of inward currents in retinal glial cell 1303-4. Peak currents are plotted against test potentials (holding potential, $-100 \mathrm{mV}$ ). Inset, Current trace evoked with a pulse from a holding potential of $-100 \mathrm{mV}$ to test potential of $+10 \mathrm{mV}$. Solutions were as in Figure 2.

the proliferative response of retinal glial cells to bFGF involves a dihydropyridine-sensitive mechanism.

\section{Discussion}

bFGF is a good candidate as a molecule that may play a role in retinal pathobiology. Importantly, bFGF is present in the mammalian retina (Gospodarowicz et al., 1986). Also, it can be detected in the vitreous of patients with various retinal disorders (Sivalingam et al., 1990). The recent finding that glia from bovine retina have binding sites for bFGF (Mascarelli et al., 1990) suggests that these cells may be targets for this growth factor. In agreement with this possibility is our observation that bFGF is mitogenic for retinal glial cells. This proliferative effect of bFGF on glial cells of the retina is consistent with previous studies demonstrating a mitogenic response of cercbral glia to this growth factor (Gospodarowicz et al., 1985; Kniss and Burry, 1988).

Our experiments indicate that exposure to bFGF is associated with an enhancement of the L-type calcium current in retinal glial cells. Previous studies have suggested that an influx of calcium may be one of the cellular responses to bFGF. Future 
Figure 6. Differential block of $\mathrm{T}$ - and L-type currents by nifedipine, from cell 1292-2. Records show whole-cell currents before and after $\left({ }^{*}\right)$ exposure of the cell to a perfusate containing $1 \mu \mathrm{M}$ nifedipine. Voltage protocols evoked predominantly T- $(A)$ or I -type $(B)$ currents. Each trace is the average of four runs. Solutions were as in Figure 2.
A

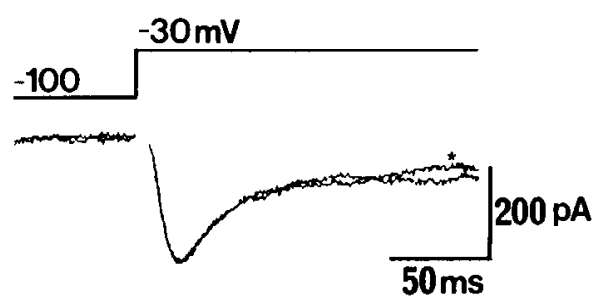

B
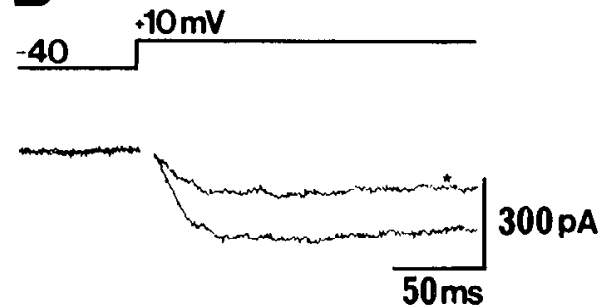

studies are needed to elucidate the mechanism by which exposure to bFGF is associated with an increase in L-type calcium currents. Possible ways for augmenting these currents include an alteration in gating kinetics, an unmasking of covert calcium channels, and changes in channel availability (Tsien et al., 1988). Although G-proteins are implicated in the regulation of L-type currents in a variety of cell types (Tsien et al., 1988; Schultz et al., 1990), our finding that pertussis toxin, an inactivator of G-proteins in many systems (Graviano and Gilman, 1987), did not block a bFGF-induced increase in barium current does not support a role for G-proteins in the modulation of calcium channels by bFGF in retinal glial cells. Our lack of evidence for involvement of G-proteins is consistent with other studies failing to find G-proteins as mediators of the effects of bFGF (Chambard et al., 1987). Also, G-protein-independent mechanisms for enhancing L-type calcium currents have been implicated for other non-neural cells (Callewaert et al., 1989; Smith et al., 1989). However, it should be noted that pertussis toxin has not been demonstrated to block G-proteins in retinal glial cells. For the future, the use of the patch-clamp technique to analyze single-channel activity will be helpful in evaluating mechanisms by which bFGF may modulate voltage-gated calcium channels in retinal glial cells.

This is the first report of voltage-gated calcium channels in glial cells from the adult mammalian CNS, though glia from the perinatal nervous system are known to express these types of channels (MacVicar, 1984; Barres et al., 1988, 1989; MacVicar and Tse, 1988; Corvalan et al., 1990), and a high-threshold calcium current has been found in glia of the salamander retina (Newman, 1985). In this study we found that the human retinal glial cells express two types of voltage-gated calcium currents ( $T$ - and L-types). The dihydropyridine nifedipine distinguishes between the two types of inward currents by blocking preferentially the L-type current.

The role of voltage-gated calcium channels in the physiology of glial cells is unclear. It seems possible that potassium released by neurons into the extracellular space could depolarize the glial cell enough to activate low-threshold, T-type calcium channels. An influx of calcium via these channels with subsequent activation of calcium-activated potassium channels perhaps could aid in the regulation of extracellular potassium levels (Newman, 1985). Although T-type currents may be activated under physiological conditions, it is less likely that glial cells would be depolarized profoundly enough to activate $L$-type calcium channels under normal conditions. However, a marked reduction in the membrane potential of glial cells may occur under pathophysiological conditions, such as anoxia or cell injury. If depolarized retinal glial cells were also exposed to bFGF, our experiments suggest that calcium influx through L-type channels would be augmented. Because calcium is involved in many important cellular events, this enhanced influx could perhaps affect significantly the response of the retina to pathophysiological conditions causing severe depolarization.

Whether there is a link between the modulation of L-type calcium currents and the proliferative response to bFGF is uncertain. The temporal correlation of exposure to bFGF and augmentation of L-type current is consistent with a possible role of these calcium channels in mediating the proliferative response of retinal glia to this growth factor. The finding that nifedipine inhibits both the L-type current and the bFGF-induced prolif-
Figure 7. Inward currents before and after exposure to $\mathrm{bFGF}$, from cell 1297 . 3. $A$, Currents elicited with pulses to 0 $\mathrm{mV}$ from a holding potential of -100 $\mathrm{mV}$ during a control period and $14 \mathrm{~min}$ after the onset of miniperfusion of the bath solution supplemented with 500 $\mathrm{pg} / \mathrm{ml} \mathrm{bFGF}$. Each trace is the average of four runs. $B$, Peak current plotted against test potential for the same cell as $A$ (holding potential, $-100 \mathrm{mV}$ ) before $(O)$ and 15 to $20 \mathrm{~min}$ after $(\mathbf{O})$ bFGF-exposure.
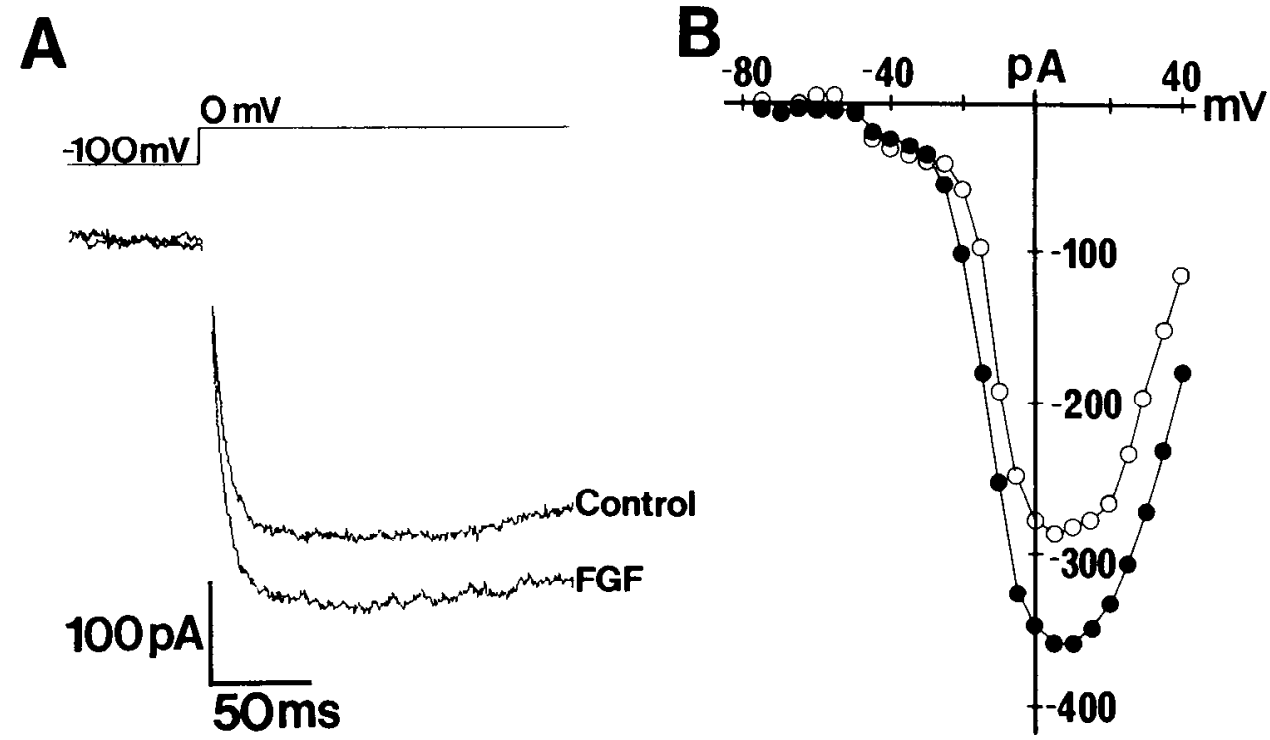


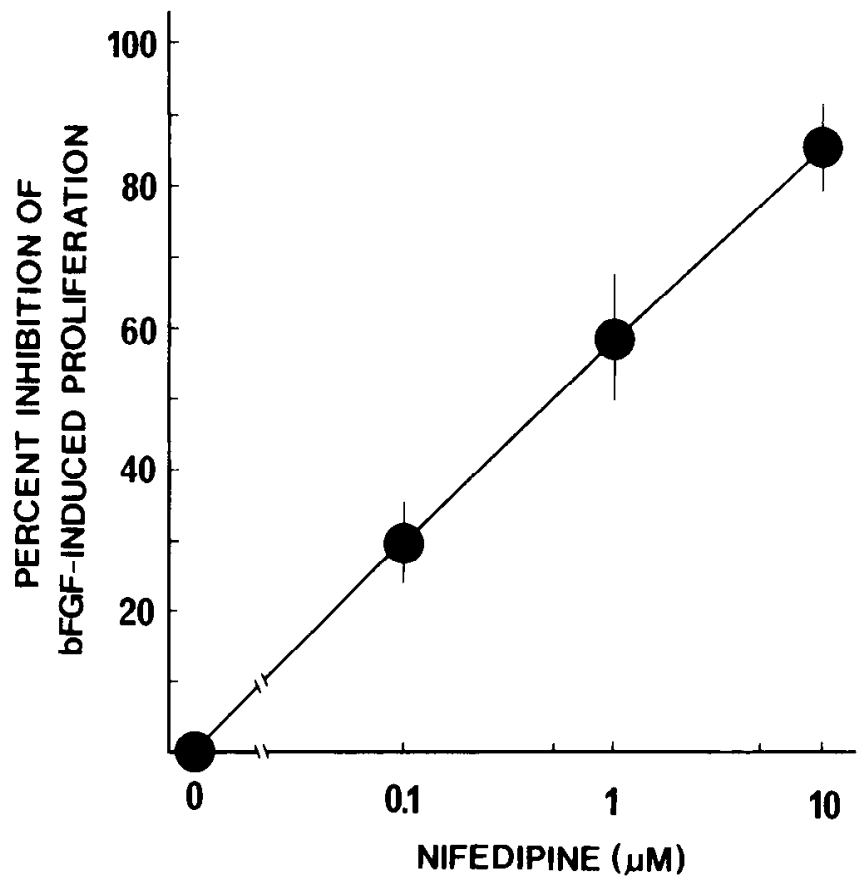

Figure 8. Dose-response curve for the percent inhibition by nifedipine of retinal glial cell proliferation induced by bFGF. Cultures of human retinal glial cells were incubated in medium B supplemented with 100 $\mathrm{pg} / \mathrm{ml} \mathrm{bFGF}$ and various concentrations of nifedipine. The change in cell number was determined after $2 \mathrm{~d}$. For each point, cells in 6-12 plates were counted. Points represent the mean percent inhibition; bars show SDs.

eration of glia further suggests that dihydropyridine-sensitive channels may play a role in this mitogenic response. However, definitive proof of a link between calcium currents and proliferation remains to be established. For example, at present it is not known precisely how raised intracellular calcium levels would lead to or provide an environment conducive for DNA synthesis. Also, a concern regarding our experiments is the possibility that nifedipine affects other cellular events in addition to calcium channels. We cannot exclude this possibility, though the half-maximal concentration for the block of glial proliferation by nifedipine is approximately $0.5 \mu \mathrm{M}$, a relatively low dose of this dihydropyridine. Also, an important unresolved issue is whether retinal glial cells become depolarized sufficiently after bFGF exposure for the high-threshold calcium channels to becomc activated. Our monitoring of the membrane potentials of retinal glial cells indicates that bFGF does not induce a rapid ( $<15 \mathrm{~min}$ ) reduction in membrane potential to the level necessary to activate L-type currents (D. G. Puro, unpublished observations). Despite this, it is possible that, over longer periods during the cell cycle, significant transient changes in the membrane potential may occur. Activation of sodium channels and/or divalent permeable nonspecific calcium channels, which are expressed by the human retinal glial cells (Puro, 1991), is a possible mechanism for eliciting transient depolarizations. Perhaps intermittent depolarizations during the cell cycle activate influxes of calcium via L-type channels. Further experiments are required to evaluate these possibilities.

The culture system used here appears to be a reasonable system in which to study aspects of the pathophysiology of human retinal glial cells. The cells in culture are immunoreactive to antibodies specific for GFAP and Müller's cells (Mano and Puro, 1990; Puro et al., 1990), as are cells often found in multicellular complexes (so-called epiretinal and preretinal "membranes") located on the retinal surface or extending into the vitreous in eyes with various retinal diseases (Rodrigues et al., 1981; Hiscott et al., 1984; Chan et al., 1986, 1988; Jerdan et al., 1989; Sramek et al., 1989; Vinores et al., 1990). However, despite these similarities, it remains to be demonstrated that the ion channels found in the cultured cells are, in fact, also expressed by retinal glial cells in vivo. Although in vivo electrophysiological studies of calcium channels in retinal cells are lacking, the finding of voltage-gated calcium current in Müller's glia in a slice preparation of the salamander retina (Newman, 1985) strongly suggests that certain calcium channels are present in these cells in vivo at least in some vertebrates. Clearly, an in vitro system is essential in order to use the patch-clamp technique to study cells of the human retina. An advantage of a cell culture system is the ability to assay the effects on human retinal glial cells of defined concentrations of specific growth factors under serumfree conditions in the absence of significant numbers of nonglial cells.

Although bFGF influences retinal glial cells in vitro, this remains to be demonstrated in vivo. An important issue concerning bFGF actions in vivo is how this molecule is secreted from cells, because it lacks a signal sequence (Abraham et al., 1986; Rifkin and Moscatelli, 1989). In addition, effects of bFGF may be limited by the strong affinity of this growth factor for the extracellular matrix (Folkman et al., 1988; Rifkin and Moscatelli, 1989). Whether unbound, extracellular bFGF is available under normal physiological conditions in the retina or brain is unknown. It has been postulated that bFGF may be released during ischemia and/or cell damage (Gajdusek and Carbon, 1989; Rifkin and Moscatelli, 1989). Quantification of changes in bFGF levels in the retina with disease or injury is lacking. However, in the brain, increased levels of bFGF-like immunoreactivity are found adjacent to wound sites (Finkelstein et al., 1988).

Our experiments suggest that exposure to bFGF may stimulate the proliferation of retinal glial cells by a dihydropyridinesensitive mechanism. A proliferation of glia may be an adaptive response of the nervous system resulting in the creation of more glial cells that would help regulate potassium levels and remove potentially toxic molecules, such as glutamate. On the other hand, the proliferation of glial cells often is a significant factor in compromising neural function with disease or injury. For example, in the retina, proliferating glia can become part of multicellular complexes that may reduce neuronal function by causing detachment of the retina from the underlying retinal pigment epithelium (Laqua and Machemer, 1975). Whether drugs such as nifedipine may be useful in modifying the detrimental responses of glial cells to pathological conditions remains to be determined.

\section{References}

Abraham JA, Whang JL, Tumolo A, Mergia A, Friedman J, Gospodarowicz D, Fiddes JC (1986) Human basic fibroblast growth factor: nucleotide sequence and genomic organization. EMBO J 5:25232528.

Barres BA, Chun LLY, Corey DP (1988) Ion channel expression by white matter glia: 1 . Type 2 astrocytes and oligodendrocytes. Glia 1: $10-30$.

Barres BA, Chun LLY, Corey DP (1989) Calcium current in cortical 
astrocytes: induction by cAMP and neurotransmitters and permissive effect of serum factors. J Neurosci 9:3169-3175.

Bean BP (1989) Classes of calcium channels in vertebrate cells. Annu Rev Physiol 51:367-384.

Callewaert G, Hanbauer I, Morad M (1989) Modulation of calcium channels in cardiac and neuronal cells by an endogenous peptide. Science 243:663-666.

Chambard JC, Paris S, L'Allemain G, Pouyssegur J (1987) Two growth factor signalling pathways in fibroblasts distinguished by pertussis toxin. Nature 326:800-803.

Chan C-C, Fujikawa LS, Rodrigues MM, Stevens G, Nussenblatt RB (1986) Immunohistochemistry and electron microscopy of cyclitic membrane. Arch Ophthalmol 104:1040-1045.

Chan C-C, Palestine AJ, Kuwabara T, Nussenblatt RB (1988) Immunopathologic study of Vogt-Koyanagi-Haradi syndrome. Am J Ophthalmol 105:607-611.

Corvalan V, Cole R, DeVelles J, Hagiwara S (1990) Neuronal modulation of calcium channel activity in cultured rat astrocytes. Proc Natl Acad Sci USA 87:4345-4348.

Faktorovich EG, Steinberg R, Yasumura D, Matthes MT, LaVail MM (1990) Photoreceptor degeneration in inherited retinal dystrophy delayed by basic fibroblast growth factor. Nature 347:83-86.

Finkelstein SP, Apostolides PJ, Caday CG, Prosser J, Phillips MF, Klagsbrun M (1988) Increased basic fibroblast growth factor (bFGF) immunoreactivity at the site of focal brain wounds. Brain Res 460 : 253-259.

Folkman J, Klagsbrun M, Sasse J, Wadzinoski M, Ingber DE, Vlodavsky (1988) A heparin-binding angiogenic protein-basic fibroblast growth factor-is stored within basement membrane. Am J Pathol 130:393400

Fox AP, Nowycky MC, Tsien RW (1987) Kinetic and pharmacological properties distinguishing three types of calcium currents in chick sensory neurons. J Physiol (Lond) 394:149-172.

Gajdusek CM, Carbon SL (1989) Injury-induced release of basic fibroblast growth factor from bovine aortic endothelium. J Cell Physiol 139:570-579.

Gospodarowicz D, Massoglia S, Cheng J, Lui G-M, Bohlen P (1985) Isolation of bovine pituitary fibroblast growth factor purified by fast protein liquid chromatography (FPLC). Partial chemical and biological characterization. J Cell Physiol 122:323-393.

Gospodarowicz D, Neufeld G, Schwigerer L (1986) Molecular and biological characterization of fibroblast growth factor, an angiogenic factor which also controls proliferation and differentiation of mesoderm and neuroectoderm derived cells. Cell Differ 19:1-17.

Graviano MP, Gilman $\Lambda \mathrm{G}$ (1987) Guanine nucleotide-binding regulatory proteins: mediators of transmembrane signaling. Trends Pharmacol Sci 8:478-481.

Guerin CJ, Wolfshagen RW, Eifrig DE, Anderson DH (1990) Immunocytochemical identification of Müller's glia as a component of human epiretinal membranes. Invest Ophthalmol Vis Sci 31:10471055.

Hamill DP, Marty A, Nehr E, Sakmann B, Sigworth FJ (1981) Improved patch clamp techniques for high resolution current recordings from cells and cell-free membrane patches. Pfluegers Arch 391:85100.

Hamilton C, Chandler D, Klintworth G, Machemer R (1982) A transmission and scanning electron microscopic study of surgically excised preretinal membrane proliferations in diabetes mellitus. Am J Ophthalmol 94:473-488.

Hiscott PS, Grierson I, Trombretta CJ, Rehi ANS, Marshall J, McLeon D (1984) Retinal and epiretinal glia - an immunohistochemical study. Br J Ophthalmol 68:698-707.

Hjelmeland LM, Harvey AK, Hohman TC, DeJuan E Jr (1987) Primary culture and chemotactic responses of human retinal glia. Invest Ophthalmol Vis Sci [Suppl] 28:208.

Jerdan JA, Pepose JS, Michels RG, Hayashi H, DeBustros S, Sebag M, Glaser BM (1989) Proliferative vitreoretinopathy membranes. An immunohistochemical study. Ophthalmology 96:801-810.
Kniss DA, Burry RW (1988) Serum and fibroblast growth factor stimulate quiescent astrocytes to reenter the cell cycle. Brain Res 439: 281-288.

Laqua H, Machemer R (1975) Glial cell proliferation in retinal detachment (massive periretinal proliferation). Am J Ophthalmol 80: 602-618.

MacVicar BA (1984) Voltage-dependent calcium channels in glial cells. Science 226:1345-1347.

MacVicar BA, Tse FWY (1988) Norepinephrine and cyclic adenosine $3^{\prime}: 5^{\prime}$-cyclic monophosphate enhance a nifedipine-sensitive current in cultured rat astrocytes. Glia 1:350-365.

Magnaldo I, L'Allemain G, Chambard JC, Moenner M, Barretault D, Pouyssegur J (1986) The mitogenic signaling pathway of fibroblast growth factor is not mediated through polyphosphoinositide hydrolysis and protein kinase $\mathrm{C}$ activation in hamster fibroblasts. $\mathrm{J}$ Biol Chem 261:16916-16922.

Mano T, Puro DG (1990) Phagocytosis by human retinal glial cells in culture. Invest Ophthalmol Vis Sci 31:1047-1055.

Mascarelli J, Tassin J, Courtois Y (1990) Fibroblast growth factor phosphorylation and receptors in rod outer segments. Interaction with glial cells: intracrine and paracrine role in retina. Invest Ophthalmol Vis Sci [Suppl] 31:227.

Newman EA (1985) Voltage-dependent calcium and potassium channels in retinal glial cells. Nature 317:809-811.

Nork TM, Wallow IHL, Sramek SJ, Anderson G (1987) Müller's cell involvement in proliferative diabetic retinopathy. Arch Ophthalmol 105:1424-1429.

Pandrella A, Magni M, Meldolesi J (1989) Plasma membrane hyperpolarization and $\left[\mathrm{Ca}^{2+}\right]_{i}$ increase induced by fibroblast growth factor in NIH-3T3 fibroblasts. Biochem Biophys Res Commun 163:13251331 .

Puro DG (1991) A calcium-activated, calcium-permeable ion channel in human retinal glial cells: modulation by basic fibroblast growth factor. Brain Res, in press.

Puro DG, Mano T, Chan C-C, Fukuda M, Shimada H (1990) Thrombin stimulates the proliferation of human retinal glial cells. Albrecht von Graefes Arch Klin Exp Ophthalmol 228:169-173.

Rifkin DB, Moscatelli D (1989) Recent developments in the cell biology of basic fibroblast growth factor. J Cell Biol 109:1-6.

Rodrigues MM, Newsome DA, Machemer R (1981) Further characterization of epiretinal membranes in human massive periretinal proliferation. Curr Eye Res 6:311-315.

Schultz G, Rosenthal W, Hescheler J (1990) Role of G proteins in calcium modulation. Annu Rev Physiol 52:275-292.

Sicvers J, Hausmann B, Unsicker K, Berry M (1987) Fibroblast growth factors promote the survival of adult rat retinal ganglion cells after transection of the optic nerve. Neurosci Lett 76:157-162.

Sivalingam A, Kenney J, Brown GC, Benson WE, Donoso L (1990) Basic fibroblast growth factor levels in the vitreous of patients with proliferative diabetic retinopathy. Arch Ophthalmol 108:869-872.

Smith PA, Rorsman P, Ashcroff FM (1989) Modulation of dihydropyridine-sensitive $\mathrm{Ca}^{2+}$ channels by glucose metabolism in mouse pancreatic B-cell. Nature 342:550-553.

Sramek SJ, Wallow IH, Stevens TS, Nork TM (1989) Immunostaining of preretinal membranes for actin, fibronectin and glial fibrillary acidic protein. Ophthalmology 96:835-841.

Tsien RW, Lipscombe D, Madison DV, Bley KR, Fox AP (1988) Multiple types of neuronal calcium channels and their selective modulation. Trends Ncurosci 11:431-438.

Van Horn DL, Aaberg T, Machemer R (1975) Glial cell proliferation in human retinal detachment with massive periretinal proliferation. Am J Ophthalmol 80:1-23.

Vinores SA, Campachiaro PA, Conway BP (1990) Ultrastructural and electron-immunocytochemical characterization of cells in epiretinal membranes. Invest Ophthalmol Vis Sci 31:14-27.

Yong VW, Kim SU, Pleasure DE (1988) Growth factors for fetal and adult human astrocytes in culture. Brain Res 444:59-66. 